\title{
Current Scenario of Medical Tourism in Chennai its Aspects and Strategies
}

\author{
Vimitha $^{1}$, V. Shobana ${ }^{2}$ \\ M.Phil Scholar, Anna Adarsh College for Women, Chennai
}

\begin{abstract}
Tourism is a ongoing industry that is highly influenced by economic value and potential growth. The development of various infrastructure facilities has led way for many visitors from all around the world for various purposes. In tourism industry medical tourism field is the developing field that is attracting foreign patients from other countries to Chennai for various treatments. In Chennai medical tourism plays a important role as it provides treatments in affordable price with is $10 \%$ less compared to cost of treatment that is available in United States. This study attempts to bring out the ongoing facilities in Chennai, about famous hospitals that are providing best treatments to abroad patients and the development procedures that are adopted. The current medical tourism in Chennai attracts most of the other country patients who become aware of many hospitals in Chennai through websites and Indian doctors who work abroad. Medical tourists choose Chennai because of low costs of health care with international high standard. It also has hospitals minimal acceptable high standard of care minus the ambience for extremely costconscious patients who need urgent medical care but with limited financial resources.
\end{abstract}

Keywords: Foreign patients, development procedures, medical tourism, international standard and financial resources

\section{Introduction}

Tourism is a multidimensional activity. The success of travel and tourism activity depends upon the success of travel and tourism activity depends upon the success of a number of other sectors. Tourists are travelling with various purposes like leisure and recreation, business and professional journeys. India is a country with immense tourism resources. Diversification and enrichment of the existing resources will help the country immensely. A remarkable trend in the tourism activities is the growth and popularity of health care holidays based on medical tourism.

Tourism is a complex industry that includes a variety of economic activities, services and demand supply patters. The most important factor is the availability of strong resource base. Tourism development largely depends on the variety of richness of tourist resources. During the recent years the tourism industry has witnessed unique growth. Increasing consumer demand for educational and participatory travel experiences has resulted in a variety of specialty niche markets such as ecotourism, culturalheritage tourism and agri tourism. Global trends in travel and tourism have been revolving around the major tourism activities which helps a tourist to visit places for the purpose of destinations, attractions, and alsolearning about the culture and traditions of that particular country.

\section{Medical Tourism Growth and Opportunities}

Medical tourism is an important element in tourism industry. It is also known as medical travel or health tourism. As costs of the treatment has increased people have started to travel or health tourism. As costs of the treatment has increased people have started to travel from various parts of India for attaining treatments. Travelling for medical purposes has become an important part of global economy. The physical, economic and cultural borders that once separated the nations from one another are wearing away as international travel, mass communication, and more lenient trade policies make it possible for those with modest means to enjoy world class medical treatments. Medical tourism can be broadly defined as enjoy world class medical treatments.

Medical tourism can be broadly defined as provision of cost effective private medical care in collaboration with tourism industry for patients needing surgical and other forms of specialized treatment. It is a term initially coined by travel agencies and medical care to describe the rapidly growing practice of travelling across international borders to obtain healthcare.

Health tourism relates to travel associated with medical treatment, rejuvenation and wellness therapies. Though mainly focusing on cross border travel it also focuses on interstate travel for the purpose of health care. The health tourism market, which is estimated to be 67billion and growing at a rate of $20 \%$ can broadly be divided into three segments orthopedic, cardiac and other surgeries, plastic or cosmetic surgery and health spas, yoga therapy etc. private hospitals are in forefront of the health care industry. The health care industry can broadly be classified into alternative healthcare services provided through yoga, naturopathy, Ayurveda, yunani medicine, meditation and kerala health retreat and corporate healthcare services provided through competent private hospitals like Apollo and Fortis. The health care industry faces challenges like infrastructural facilities, expectations of the foreign patients regarding the quality of medical services provided to them, accessibility of Indian market to the foreigners, competition with neighbors. Insurance back up and match between local and global healthcare demand.

\section{Medical Tourism in Chennai}

The South Indian city of Chennai has become the hub of medical tourism in India. Patients from all over the country (the North Eastern states) and abroad come to the city for medical treatment. Patients from Africa, Nigeria, Kenya, 


\section{International Journal of Science and Research (IJSR) \\ ISSN (Online): 2319-7064}

Index Copernicus Value (2015): 78.96 | Impact Factor (2015): 6.391

and Congo), Bangladesh, and the Middle East frequent the city for quality medical care. The recuperating patients and their companions then go on sightseeing tours, organized by the hospitals.

Most of these reputed hospitals maintain a separate wing for international patients. Ramachandra Hospital at Porur in Chennai receives about 100 international patients each day. Similarly, Fortis Malar receives about 20 overseas patients each day. Cardiac, orthopedics, neurosurgery, and oncology are the main branches in which medical treatment is being sought by these foreign patients. Hospitals like Madras Medical Missions have tie-ups with foreign governments. The last named hospital receives about 20 medical tourists from East African countries, mainly for cardiac surgeries and kidney ailments including kidney transplants.

SankaraNetralyaya receives about 500 overseas patients a month for eye-related problems. The hospital also takes care of other patients coming from all over India. T.I.Joshua, Manager-International Business of Fortis Malar says that they get 15 to 20 patients a month from around the world,' he also said that "Treatment for cardiac, orthopaedic, and neurosurgery are the main reasons for people choosing this hospital. Mr.Joshua believes that many countries have fully-equipped hospitals but lack specialists and experienced nurses. This hospital also provides rental accommodation for patient's relatives. "The service apartments in Adyar charge between Rs.2,500 and Rs.4,000 a night. We have recently started service apartments for Rs.1,500 per night," he adds.

Several private hospitals in Chennai have tied up with governments of other countries. Representatives of Madras Medical Mission say that every month, 14 persons from abroad, mainly from East African nations, come to the hospital as medical tourists. The hospital is preferred by international patients for kidney transplants and cardiac surgeries. Besides overseas patients, a sizeable number of patients come from within India. While some of the patients like Om Mahajan from Nagpur come to the city on doctors' advice, several others choose Chennai for quality health care.

The increase in overseas patients' visit to the city has paved way for companies to facilitate medical tourism. Jose Manavalan, Chief Executive Officer of one such organisation that operates in T.Nagar, says international patients choose Chennai for quality and cost-effective healthcare. The officer has tie up with many hospitals along with other chief officials who take care of the selection of hospitals treatment, travel, accommodation, follow-up camps and organizing tourists in their country.

Medical tourism in the 21st century has become a major earner of foreign exchange for many nations. Many places in Chennai have started depending on medical tourists arrival to various parts of Chennai. The medical hospitals in Chennai has rich medical professionals and well developed private hospitals which offers a high quality medical care and with economical treatments.
Medical tourism in India is synonymous with Chennai, the state plays a vital role in the expanding medical tourism industry. The state is pioneer in providing the health care. Ultra modern corporate hospitals, talented medical professionals and battalions of paramedics and the best practices of government hospitals have attracted people to the state to receive excellent treatment, recover in enchanting locales and recuperate swiftly. Hospitals in Chennai cater to the treatment of various diseases like MIOT for orthopaedics and traumatology, Shankar Netralaya for ophthalmology, Christian medical college for open heart surgery, Madras Medical Mission for heart surgery, Kovai medical centre and hospital for arthoscopic, Laproscopic and thoracoscopic surgeries, and Apollo for hip and total-Knee replacement, liver, multi organ and cord blood transplants

Health care in Chennai has earned a good reputation from other countries from which foreign tourists arrive to seek medical treatments. Hospitals in Chennai are famous because both private and government hospitals are so professional. Envisioning the potential of medical tourism in the city. Chennai has come a long way in carving a niche for itself in this field. Medical tourism in Chennai, a stellar role to play in the burgeoning medical tourism industry. Chennai is pioneer in providing the best healthcare. Ultra modern corporate hospitals, talented medical professionals, battalions of paramedics and best practices of government hospitals in the state, have attached people to the city, have attracted people to the city to receive excellent treatments convalesce in enhancing locales, and recuperate swiftly. The government medical college is well known for its gastrointestinal procedures. Also government led general hospitals is well known for providing servicesupto 7,000 in patients alone. The investment in public sector hospitals is substantial, which they are able to offer state of the art operation theatres and technology at cost effective prices. The medical tourism has been promoted by the government by identifying 25 city hospitals to help showcase medical tourism as well as inaugurated an exclusive medical tourism desk at the Chennai tourism complex. The medical desk would be manned by trained staff to help tap the vast potential of tourism.

Chennai attracts about $40 \%$ of the country's medical tourists and more than six lakh tourists visit the state every year, according to a study by Confederation of Indian Industries (CII). The inflow of medical tourists to India has increased by $23 \%$, with Chennai continuing to be the favorite destination, said CII officials.

The city receives up to 200 foreign patients every day owing to the quality of healthcare, said S Chandrakumar, convener of the CII healthcare panel, at the international conference and exhibition on health tourism in Chennai Trade Centre on Friday. International patients seeking urgent medical care, in a different country became an attractive industry worldwide by the turn of 21 st century. The ease and lower cost of travel catapulted the industry into limelight. Patients undertook travel for treatment for varied reasons. People travel from other places to Chennai mainly for the purpose getting best treatments this is due to the lack of facility and cost advantage in their own country. Estimates indicated 


\section{International Journal of Science and Research (IJSR) \\ ISSN (Online): 2319-7064 \\ Index Copernicus Value (2015): 78.96 | Impact Factor (2015): 6.391}

that the number of foreign patients was growing $30 \%$ each year in Chennai.

Around 8.5 lakh tourists visited India in 2011 for treatment. Last year, it increased to 1.1 million, said Chandrakumar. Through the two-day expo, CII and Tamil Nadu Tourism Development Corporation hope to give a fillip to Chennai as a preferred medical tourist's city.The city produces the maximum number of doctors and paramedics in the country, said health secretary Dr J Radhakrishnan states that "Many tourists from the Middle-east, Africa, South and Southeast Asia come to chennai every year," he said. He said the government plans to build a 'medicity' with public-private partnership under the vision 2023 programme, which will expand the scope of medical tourism in the state.

Specialty wise international patients recieved treatment in Chennai hospitals

\begin{tabular}{|c|c|c|}
\hline S.no & Specialty & No.of patients \\
\hline 1 & Cardio thoracic surgery & 38 \\
\hline 2 & Plastic surgery & 49 \\
\hline 3 & Ophthalmology & 58 \\
\hline 4 & Gynecology and obstetrics & 09 \\
\hline 5 & Laproscopic surgery & 49 \\
\hline 6 & Dental & 32 \\
\hline
\end{tabular}

(As per survey done in few hospitals in Chennai)

Satisfaction level of international patients received treatment in hospital

\begin{tabular}{|c|c|c|c|c|c|}
\hline S.No & Services & $\begin{array}{c}\text { Very } \\
\text { Good }\end{array}$ & $\begin{array}{c}\text { Good } \\
\%\end{array}$ & $\begin{array}{c}\text { Average } \\
\%\end{array}$ & $\begin{array}{c}\text { Below } \\
\text { average } \%\end{array}$ \\
\hline 1 & Medical treatment & 85 & 13.8 & 0.64 & 00 \\
\hline 2 & Medical services & 88 & 10.5 & 0.43 & 00 \\
\hline 3 & Nursing services & 88.7 & 10.5 & 0.64 & 00 \\
\hline 4 & Food and beverage & 77.75 & 21.1 & 1.07 & 00 \\
\hline 5 & Administrative staff & 83.8 & 14.9 & 1.29 & 00 \\
\hline
\end{tabular}

\section{Literature Survey}

The health care services in Chennai are provided both by private and government hospitals. Chennai attracts more number of patients from abroad for its best available treatments provided at lower costs. The survey is done through primary sources which is are the informations collected from various hospitals in Chennai. A personal visit to famous hospitals in Chennai is done and an oral discussion with many surgeons of the hospital is carried out to get general idea about the purpose of visit of foreign patients.

\section{Methods}

The research area is addressed through interaction with the foreign patients in order to know their purpose of visit of treatment in that particular hospital. Foreign patients are mostly from northIndia and from countries like united states to other developed countries of Europe.

\section{Discussion}

Medical tourism is fundamentally different from the traditional model of international medical travel where patients generally journey less developed nations to major medical centres in highly developed countries for medical treatment that is available in their own country. The term medical tourism does not accurately reflect the reality of the patient situation or the advanced medical care provided in these destinations. Stem cell therapy for any number of problems may be available or restricted in industrialized countries, but may be much more available in Chennai.

The exotic locations and vacation in affordable luxurious surroundings. The primary reason for medical centres in Chennai able to healthcare services inexpensively is directly related to nation's economic status. The prices charged in Chennai are able to provide healthcare services inexpensively is directly related to the nation's economic status.

Medical tourism, the available information suggests that a substantial number of patients travel to developing nations for health care. In 2016 more than $80 \%$ of the population of the foreign patients have travelled to Chennai.

\section{Conclusion}

Tourism is an important economic activity in the city of Chennai, to which medical tourism has been an increasingly important contributor. Chennai currently accounts for $45 \%$ of all of India's \$2 billion medical tourism industry, and an additional 30-40\% of health tourism from nationals (Macguire, 2007). While the city of Chennai and the state of Tamil Nadu may have an extensive network of healthcare facilities and infrastructure, there is strong reason to believe that they are not currently meeting local needs for access to medical care. The country as a whole faces crucial health personnel challenges, with $70 \%$ of the total health workforce employed in the private sector (Rao, et al., 2011); and not surprisingly creating increased dependency on private healthcare providers who are presently treating $78 \%$ of all outpatients and $60 \%$ of all inpatients (Wennerholm and Scheutz, 2013). At the same time India has actively promoted the outflow of health workers in hopes of capturing remittances, a pursuit that may be unable to compensate for the loss of qualified personnel for its domestic population. There are still large segments of the Indian population that experience economic deprivation and inadequate access to health care, and only a very small percentage covered by any form of health insurance (Yip and Mahal, 2008). While Chennai's growing medical tourism industry may bring with it opportunities to retain health human resources and improve access to advanced medical technologies, it must not do this at the cost of achieving universal, quality healthcare for local residents

\section{References}

[1] Prem jagyasi, Drprem guidebook medical tourism, create space independent platform, India, 1983.

[2] Annamalai murugan, medical tourism potential prospects and emerging issues, abhjeet publications, new delhi,2012.

[3] Amithaba ghose, health tourism a case study for India, icfai university press, India, 2012.

\section{Volume 6 Issue 7, July 2017 www.ijsr.net}




\section{International Journal of Science and Research (IJSR) \\ ISSN (Online): 2319-7064}

Index Copernicus Value (2015): 78.96 | Impact Factor (2015): 6.391

[4] Anurag kothari, tourism management, wisdom press, new delhi, 2011

[5] "Chennai remains favorite destination for medical tourists"( article times of India. India times/2013health tourism medical tourists)Chennai: times group, 28 april 2013.

[6] Ross kim, " health tourism: an overview, marketing review, hospitalitynet.org/news.

[7] koul Jyothi (2004): "medical tourism: the perfect cure", express travel and tourism, july 2014. 